\title{
Changes in yellow bristle grass (Setaria pumila) incidence in Waikato dairy pastures over 4 years
}

\author{
K.N. Tozer, C.A. Cameron and T.K. James \\ AgResearch Ltd, Ruakura Research Centre, Private Bag 3123, Hamilton 3240, \\ New Zealand \\ Corresponding author: Katherine.Tozer@agresearch.co.nz
}

\begin{abstract}
Thirty-nine Waikato dairy pastures have been surveyed annually each February, for 5 years, to quantify changes in cover of yellow bristle grass and to determine if management factors influence this. After a severe drought, yellow bristle grass ground cover increased from 4 to $11 \%$ (2008 to 2009) and has since remained at this level. Ryegrass cover declined after the drought and has not returned to pre-drought levels while clover cover has increased. There was a much higher than average 2011/2012 summer rainfall, possibly causing the reduced summer grass and broadleaf weed cover measured in February 2012. By the end of the survey period, there was no reduction of yellow bristle grass cover from any of the following farm practices aimed to improve pasture performance: summer cropping, undersowing, oversowing and non-selective herbicide applied during summer.
\end{abstract}

Keywords yellow bristle grass, Setaria pumila, survey, incursion, pasture, ground cover.

\section{INTRODUCTION}

Yellow bristle grass (Setaria pumila) is a C4 annual grass weed that is prevalent in the central North Island of New Zealand. Milk production will be reduced on pastures infested with yellow bristle grass because its forage quality is poor (Tozer \& James 2011). Dairy cattle may also avoid grazing plants with mature seed heads, which can reduce the available forage.

Yellow bristle grass establishes in early summer and can produce seeds within 4 weeks. In a typical dairy pasture mature plants can produce new seed heads between grazings (Tozer \& Cameron 2009). Its seed production is prolific; a single seed head may contain hundreds of seeds (Forcella et al. 2000). It is thought that seeds are being spread by maize contractors, farm machinery and roadside mowers. They can also be spread by effluent and survive passage through livestock (James et al. 2009). Farmers are concerned about its spread and report that it is rapidly invading new paddocks. This is supported by Climex modelling, which indicates that much of the North Island and eastern South Island is climatically suitable for yellow bristle grass (James 2011).

Control methods to date have been limited, although wrapped balage and silage are effective in destroying yellow bristle grass seeds (James et al. 2009). More recently, the herbicide fenoxaprop-Pethyl has been found to selectively kill yellow bristle grass in temperate perennial pastures without damage to the sown grasses or clovers (T.K. James, unpublished data). Research is currently underway to ascertain a suitable livestock withholding period from grazing for this chemical. 
Given the concern about the spread and impact of this weed, 39 dairy pastures in central Waikato where yellow bristle grass is prevalent have been surveyed each February for the last 5 years (2008 -2012), to quantify its rate of spread. In addition, data were obtained from farmers on key pasture management practices that might influence yellow bristle grass spread within these paddocks. This included pasture renewal practices, the use of summer crops, herbicide application, topping, and oversowing (broadcasting seed onto the surface) or undersowing (drilling seed into the existing pasture) since renewal. This paper reports on 5 years of botanical composition data and their relationship to farm management practices.

\section{METHODS}

Twelve dairy farms were randomly selected within a $50 \mathrm{~km}$ radius of Te Awamutu, in central Waikato, which is an area known to have a high incidence of yellow bristle grass. On each farm, two to four paddocks were selected, to give a total of 39 paddocks. Pastures varied in size ( 1 to $3 \mathrm{ha}$ ) and in their age and renewal history. All farms were rotationally grazed by dairy cows. The rotation length over summer varied between years and farms but was mostly 3 to 4 weeks.

Four $2 \mathrm{~m} \times 2 \mathrm{~m}$ quadrats were randomly placed using stratified random sampling within each paddock, based on paddock topography. The percentage ground cover of ryegrass, clover, yellow bristle grass, summer grass and broadleaf weeds was visually estimated and all species present in the quadrat recorded. Paddock management history data were obtained from the farm manager for each of the paddocks surveyed, including pasture renewal, cropping, under- or over-sowing of pastures since renewal and non-selective herbicide use for yellow bristle grass control since January 2008. Between 3 and 5 paddocks were renewed each year, nearly all of which used a summer crop (chicory, maize or turnips) as part of the renewal process prior to sowing the perennial pasture. This involved applying glyphosate to the old pasture in September/October and cultivating then sowing the summer crop in October/November. In at least one of the 4 years between 2009 and 2012, $5 \%$ of surveyed paddocks had a non-selective herbicide applied to target yellow bristle grass, $18 \%$ were cultivated, $23 \%$ had a summer crop and $31 \%$ were undersown. Paddocks were not surveyed in the year in which they contained a crop.

Summer rainfall varied considerably over the 5 years. In 2008 there was a severe drought, with Hamilton in Waikato receiving only $97 \mathrm{~mm}$ of rain (December 2007-February 2008). It was the second driest summer in Hamilton since recording of rainfall began in 1920. However, in 2012 the rainfall was well above the average and in the 3 years in between, summer rainfall was close to or above the long-term average (Table 1).

All statistical analyses were done using GenStat. Botanical data (including yellow bristle grass cover) were pooled for each paddock and arc sine transformed where necessary to normalise the variance. In addition to ground cover data, presence/absence of yellow bristle grass in quadrats or paddocks was analysed. The effect of management practices on yellow bristle grass cover was analysed using Restricted Maximum Likelihood analysis (REML), fitting farms and paddocks within farms as random effects. Changes in botanical composition between 2008 and 2012 were tested with a repeated measures REML analysis.

\section{RESULTS}

The percentage of quadrats in which yellow bristle grass was present increased from 46 to $69 \%$ from February 2008 to February $2009\left(\chi^{2} \mathrm{P}<0.001\right)$, but there was no significant change in the percentage

Table 1 Summer rainfall from 2008 to 2012 and long-term average rainfall (1 December-1 March, 1975 to 2004) in Hamilton obtained from New Zealand's National Climate Database.

\begin{tabular}{ccccccc}
\hline & 2008 & 2009 & 2010 & 2011 & 2012 & Long-term average \\
\hline Rainfall $(\mathrm{mm})$ & 97 & 310 & 277 & 334 & 376 & 259 \\
\hline
\end{tabular}


of paddocks containing yellow bristle grass during the same period $\left(\chi^{2} \mathrm{P}=0.130\right)$. From 2009 to 2012 there was no significant change between years in the proportion of quadrats or paddocks containing yellow bristle grass (Table 2).

Nearly all pastures had been sown with perennial ryegrass (Lolium perenne) and white clover (Trifolium repens), although some paddocks had also been planted in cocksfoot (Dactylis glomerata), tall fescue (Schedonorus arundinaceus), Italian ryegrass (Lolium multiflorum), red clover (Trifolium pratense) chicory (Cichorium intybus) or narrow-leaved plantain (Plantago lanceolata). Prevalent dicotyledonous weeds included pennyroyal (Mentha pulegium), Californian thistle (Cirsium arvense), docks (Rumex spp.), dandelion (Taraxacum officinale), hawksbeard (Crepis capillaris), hawkbit (Leontodon taraxacoides), chickweed (Stellaria media), broad-leaved and wild forms of narrow-leaved plantains (Plantago spp.), creeping mallow (Modiola caroliniana) and creeping buttercup (Ranunculus repens). The most frequent volunteer grasses were the annual summer-active grasses, yellow bristle grass and summer grass (Digitaria sanguinalis). Crowfoot grass (Eleusine indica), smooth witchgrass (Panicum dichotomiflorum), and the perennial summer-active grasses paspalum (Paspalum dilatatum) and ratstail (Sporobolus africanus) were also present in small amounts.

The percentage ground cover of yellow bristle grass, summer grass and broadleaf weeds increased significantly from 2008 to 2009, while ryegrass cover declined from 56 to $42 \%$ $(\mathrm{P}<0.001$, Table 3$)$. For the next 4 years, from 2009 to 2012, there was no significant difference in yellow bristle grass and ryegrass ground cover $(\mathrm{P}>0.05)$. Clover cover was significantly higher in 2010, 2011 and 2012 than in the first 2 years $(\mathrm{P}<0.001)$. Summer grass and broadleaf weed cover was significantly higher in 2009, 2010 and 2011 than in 2008 but ground cover of both declined in 2012 to $5 \%$, which was similar to 2008 levels $(\mathrm{P}<0.001)$.

In February 2008, those paddocks to which the management practices would be applied had a similar yellow bristle grass cover to those to which management practices would not be applied. In 2012, there was no difference in yellow bristle grass cover between the paddocks to which one or more of the farm management practices had been applied and those to which one or more of these practices had not been applied (Table 4). Of the two paddocks where non-selective herbicide was applied to target yellow bristle grass, there has been a significant increase in its cover since

Table 2 Percentage of paddocks and quadrats in which yellow bristle grass was present in each year in February.

\begin{tabular}{lccccc}
\hline & 2008 & 2009 & 2010 & 2011 & 2012 \\
\hline Quadrats (156) & 46 & 69 & 64 & 72 & 70 \\
Paddocks (39) & 72 & 89 & 75 & 82 & 83 \\
\hline
\end{tabular}

Table 3 Mean ground cover (\%) of ryegrass, clover, yellow bristle grass, summer grass and broadleaf weeds in 39 dairy pastures in February from 2008 to 2012.

\begin{tabular}{lccccccc}
\hline Species & 2008 & 2009 & 2010 & 2011 & 2012 & LSD & P-value \\
\hline Ryegrass & 56 & 42 & 36 & 40 & 48 & 6.9 & $<.001$ \\
Clover & 7 & 11 & 24 & 16 & 22 & 5.1 & $<.001$ \\
Yellow bristle grass & 4 & 11 & 11 & 12 & 12 & 4.0 & $<.001$ \\
Summer grass & 5 & 16 & 9 & 12 & 5 & 5.0 & $<.001$ \\
Broadleaf weeds & 4 & 9 & 12 & 11 & 5 & 4.3 & $<.001$ \\
\hline
\end{tabular}


$2008(\mathrm{P}=0.014)$. The non-selective herbicide was unable to prevent the incursion of yellow bristle grass.

\section{DISCUSSION}

This survey was commenced with the view of tracking the ingress of yellow bristle grass within dairy farms. The Yellow Bristle Grass Action Group was formed in 2006 by a group of farmers in central Waikato concerned about the appearance and impacts of a new grass weed (James 2007). Since its identification as a weed in this area, yellow bristle grass has spread to become a problem weed throughout Waikato, northwards to South Auckland and Northland and southwards to Taranaki. However, despite this massive recruitment into new areas, yellow bristle grass presence is not increasing within the surveyed paddocks of the original incursion area. The first year of this study was most likely affected by the severe summer drought (Tables 1 $\& 2$ ), in which much perennial ryegrass mortality was observed, and pastures were opened up to ingress of other species, such as yellow bristle grass and summer grass (Table 3 ). This would have been aided by the prolific seed production of yellow bristle grass, which can produce hundreds of seed in one plant (Forcella et al. 2000). The seeds are much larger than those of summer grass, a characteristic that would also help its establishment (James et al. 2011). Summeractive grasses have a competitive advantage over ryegrass during hot summers as they can tolerate higher temperatures and levels of solar radiation (Campbell et al. 1999). The rapid plateau in the number of yellow bristle grass sites (paddocks and quadrats, Table 2) is understandable given that the perennial ryegrass content has not changed since the year after the drought.

Of more concern is the fact that current practices that are used to increase pasture performance and have also been recommended for managing yellow bristle grass (James 2011) have either had little impact or made the situation worse (non-selective herbicides). There are many possible explanations for this. For example, it is important to sow the appropriate pasture species-endophyte combination in addition to directly targeting yellow bristle grass. One of the paddocks to which non-selective herbicide was applied to control yellow bristle grass patches was sown with AR1 endophyte. This is particularly vulnerable to black beetle (Heteronychus arator) attack in Waikato and high numbers of this pest were identified in this paddock (T.K. James, unpublished data). Reduced abundance (or cover) of ryegrass as a result of insect herbivory will make a pasture more vulnerable to yellow bristle grass invasion.

Other potential control options include preventing the establishment of yellow bristle grass from seeds in the soil seed bank. During the pasture renewal stage, a greater time in a cropping phase to deplete the soil seed bank may be desirable. Current research indicates that yellow bristle grass seed can persist in the seed bank for more than 3 years (T.K. James, unpublished data), and thus several years of cropping may be required. Cropping will be effective only if yellow bristle grass is not allowed to set seed during this phase. However, in the pastures surveyed, none of the herbicides applied as part of the

Table 4 Mean yellow bristle grass ground cover (\%) in February 2012 in relation to the application of management factors during the preceding 4 years (2008 to 2011).

\begin{tabular}{lcccc}
\hline & $\begin{array}{c}\text { No management } \\
\text { applied }\end{array}$ & $\begin{array}{c}\text { Management } \\
\text { applied }\end{array}$ & SED & P-value \\
\hline Non-selective herbicide & 10.4 & 29.4 & 7.59 & 0.014 \\
Cultivation & 11.1 & 13.9 & 5.57 & 0.959 \\
Summer crop & 10.8 & 14.6 & 5.74 & 0.864 \\
Under- or oversowing & 11.0 & 12.8 & 4.68 & 0.339 \\
\hline
\end{tabular}


cropping phase (mainly glyphosate applied prior to sowing the crops) were specifically applied to control yellow bristle grass. Another option is to prevent seeds being spread to uninfested pastures by dung. This would require implementing grazing rotations in which stock are not placed on recently renovated pastures within a few days of grazing infested pastures as yellow bristle grass seed most likely takes several days to pass through the cow. For example, it took 3 days for most seeds of giant ratstail (Sporobolus pyramidalis) to pass through the digestive system of cattle and $79 \%$ of seeds in the dung were viable (Bray et al. 1998). The registration of a selective herbicide could assist in keeping a new pasture free of yellow bristle grass by preventing its seed set in pastures and crops prior to renewal and by removing patches of yellow bristle grass that are emerging from dung in the new pasture.

\section{CONCLUSION}

On farms in central Waikato yellow bristle grass rapidly reached a constant frequency of occurrence. Climate appears to be critical in this; results infer that yellow bristle grass will most likely increase after a drought year. Farm management practices recommended to improve pasture performance and to control yellow bristle grass appear to be ineffective. Greater emphasis must be placed on a more targeted approach in which a selective herbicide would provide a useful tool.

\section{ACKNOWLEDGEMENTS}

Thanks to Undermining Weeds (C10X0811) and DairyNZ for funding this project. The assistance of Jason Hughes during the surveys was also greatly appreciated.

\section{REFERENCES}

Bray AG, Cahill L, Paton CJ, Bahnisch L, Silcock R 1998. Can cattle spread giant rat's tail grass seed (Sporobolus pyramidalis) in their faeces? Proceedings of the 9th Australian Agronomy Conference: 575-578.

Campbell BD, Mitchell ND, Field TRO 1999. Climate profiles of temperate $\mathrm{C} 3$ and subtropical C4 species in New Zealand pastures. New Zealand Journal of Agricultural Research 42: 223-233.

Forcella F, Colbach N, Kegode GO 2000. Estimating seed production of three Setaria species in row crops. Weed Science 48: 436-444.

James TK 2007. Yellow Bristle Grass - The ute guide. Ministry of Agriculture and Forestry, Wellington. ISBN 978-0-478-31135-8. 30 p.

James TK 2011. Yellow Bristle Grass - The ute guide 2nd edition. Ministry of Agriculture and Forestry, Wellington. ISBN 978-0-47838427-7. 40 p.

JamesTK, Tozer KN, RahmanA2009.Yellowbristle grass: a recent weed incursion in Waikato dairy pastures. Proceedings of the New Zealand Grassland Association 71: 39-42.

James TK, Rahman A, McGill CR, Trivedi P 2011. Biology and survival of broom corn millet (Panicum miliaceum) seed. New Zealand Plant Protection 64: 142-148.

Tozer KN, Cameron CA 2009. Sweet success: Managing yellow bristle grass (Setaria pumila) with grazing attractants in dairy pastures. Proceedings of the New Zealand Grassland Association 71: 43-47.

Tozer KN, James TK 2011. Increasing pasture productivity - tips on identification and control of yellow bristle grass and summer grass. DairyNZ Technical Series, November 2011. Issue 6: 15-19. 